\title{
THE EFFECT OF SUBSTITUTION OF FISH MEAL WITH HIGH PROTEIN PLANT FEED IN NUTRITION OF SOWS AND PIGLETS **
}

\author{
B. Živković $^{1 *}$, W. Migdal ${ }^{2}$, V. Veselinović ${ }^{3}, \check{C}^{\text {. Radović }}{ }^{1}$, \\ O. Kosovac', M. Fabjan ${ }^{1}$ \\ ${ }^{1}$ Institute for Animal Husbandry, Belgrade-Zemun; \\ ${ }^{2}$ Akademia Rolnicza, Kraków, Poland; \\ ${ }^{3}$ Bankom, Novi Beograd \\ *Corresponding author: vlada87@net.yu \\ ** Plenary invited paper. Research financed by the Ministry of Science Republic of Serbia, \\ Project BTN 351008 B
}

\begin{abstract}
The effects of use of high protein plant feed - Ekofish meal in nutrition of sows in lactation, sucking piglets and weaned piglets were investigated in this paper. Considering our previous positive experiences in use of similar feed in nutrition of weaned piglets and fatteners, objective of this paper was to evaluate the effects of use of high protein feed based on plant proteins in diets for lactating sows, suckling and weaned piglets.

Investigated feed was produced according to specific technology in production facilities of the firm Bankom in Serbia.

Investigations were carried out on the Experimental pig farm of the Institute for Animal Husbandry, Belgrade-Zemun in Serbia.

Obtained results showed that in isonitrogen mixtures the introduction of studied feed as substitute for fish meal had positive effects: by $6,18 \%$ lower losses of body mass of sows during lactation, by 1,6 shorter service period, with almost identical gain (difference of $2 \mathrm{~g}$ ) in suckling piglets, increased consumption of pre-starter by $1,1 \mathrm{~kg} /$ litter in piglets during creep feeding, and similar but by $4,73 \%$ lower cost of gain with similar feed conversion in weaned piglets.

In general, obtained results have shown that use of high protein plant feed can be recommended in nutrition of sows, suckling and weaned piglets.
\end{abstract}

Key words: high protein plant feed, sows, piglets

\section{Introduction and Literature Review}

Based on the decision of the Commission of the European Union 9/2001, 
mixtures containing fish meal can be produced only in livestock feed production facilities where feed for ruminants are not produced and which are specialized for this purpose with permit/licence granted by authorized expert institutions (Sardi et al., 2005). This fact leads to increased protests of consumers against use of animal proteins in livestock feeds which justifies further research of the possibility to exclude fish meal from diets used in pig nutrition.

Based on our earlier positive experiences in use of feed called Vitaprotein 50 imported from Belgium (Hoorick van, 2003) in nutrition of weaned piglets (Živković et al., 2007) and fatteners (Živković et al., 2006; Živković et al., 2007), which was of similar nutritive characteristics like the plant feed - Ekofish meal $\mathrm{u}$ in nutrition of weaned piglets (Adamović et al., 2006), sows, piglets and fatteners (Živković et al., 2007), objective of this paper was to evaluate the effects of use of high protein feed based on plant proteins in diets for lactating sows, suckling and weaned piglets.

Investigated feed was produced according to specific technology in production facilities of the company Bankom in Serbia.

\section{Material and methods}

Investigations were carried out on Experimental pig farm of the Institute for Animal Husbandry, Belgrade-Zemun. Trial included total of 22 sows in two nutrition treatments. Distribution criteria were origin of the animal, farrowing parity and boars used for their insemination.

Ten day prior to farrowing all pregnant heads were transferred to farrowing facility. Sows of the first group - control, and of the second - trial groups were fed diets for sukcler sows, investigated feed (table 2) was included in experimental mixture, and control mixture was based on fish meal (table 3). In all compared mixtures the level of crude proteins was equal, with remark that during lactation only sows were fed individually, and other categories had group feeding, in all categories nutrition was ad libitum.

Subsequent to farrowing, from the age of 8 days, suckling piglets were fed additional mixtures where again control mixture was based on fish meal and trial mixture based on investigated feed. After weaning, groups consisting of part of suckling piglets were formed, paying strict attention to the nutrition of piglets in trial groups, i.e. that they continue to receive diets with high protein plant feed, and control piglets diets with fish meal(table 3).

For evaluation of obtained results following parameters were used: body mass of sows prior to farrowing and at weaning, losses of body mass of sows 
during lactation, feed consumption of sows during lactation, number of live born piglets per farrowing, number of equalized piglets per litter, number of weaned piglets, average body mass of piglets at birth and weaning, average daily gain of piglets during lactation and rearing, and economical justification for introduction of investigated feed expressed as cost of $1 \mathrm{~kg}$ of gain.

Table 1. The scheme of the experiment

\begin{tabular}{|c|c|c|}
\hline Group & control & 2 experimental \\
\hline \multicolumn{3}{|c|}{ Lactating sows } \\
\hline Fish meal in the diet & + & - \\
\hline Plant high protein feedstuff in the diet & - & + \\
\hline \multicolumn{3}{|c|}{ Suckling piglets - creep feeding } \\
\hline Fish meal in the diet & + & - \\
\hline Plant highprotein feedstuff in the diet & - & + \\
\hline /Feed/head/day, kg & Ad libitum & Ad libitum \\
\hline \multicolumn{3}{|c|}{ Weaned piglets } \\
\hline Fish meal in the diet & + & - \\
\hline Plant highprotein feedstuff in the diet & - & + \\
\hline Feed/head/day, kg & Ad libitum & Ad libitum \\
\hline
\end{tabular}

Table 2. Nutritive value of the compared feedstuffs used in the experiment

\begin{tabular}{|l|c|c|}
\hline & Fish meal & $\begin{array}{c}\text { Plant highprotein } \\
\text { feedstuff }\end{array}$ \\
\hline ME,MJ/kg & 12,55 & 13,80 \\
\hline Moisture, \% & 8,0 & 8,0 \\
\hline Crude protein, \% & 65,0 & 60,0 \\
\hline Ether extract, \% & 5,0 & 5,0 \\
\hline Crude fiber, \% & 3,0 & 3,0 \\
\hline Ash, \% & 4,0 & 4,0 \\
\hline Calcium, \% & 0,90 & 0,90 \\
\hline Phosphorus total, \% & 0,54 & 0,54 \\
\hline Sodium, \% & 0,16 & 0,16 \\
\hline \multicolumn{2}{|c|}{ Some essential amino acids, g/16 gN : } \\
\hline Lysine & 7,81 & 7,83 \\
\hline Methionine + cystine & 3,71 & 4,02 \\
\hline Tryptophane & 1,00 & 1,08 \\
\hline Threonine & 4,20 & 3,98 \\
\hline
\end{tabular}


Table 3. The scheme of the nutrition of the experiment

\begin{tabular}{|l|c|c|c|c|c|}
\hline & \multicolumn{2}{|c|}{ Sows } & \multicolumn{2}{c|}{ Piglets } \\
\hline & Gestation & Lactation & $\begin{array}{l}\text { Creep } \\
\text { feeding }\end{array}$ & \multicolumn{2}{c|}{ Weaning period } \\
\hline Crude protein, \% & 13,5 & 18 & 22 & 20 & 18 \\
\hline $\begin{array}{l}\text { Ekofish meal, \% in } \\
\text { diet }\end{array}$ & - & 2,0 & 5,0 & 4,5 & 4,0 \\
\hline
\end{tabular}

The feedstuffs used in the diets: corn, wheat midllings, soybean oil meal, sunflower oil meal, fish meal, plant highprotein feedstuff - ecofish meal, milk replacer for piglets - ekolak, full fat soybean, limestone, monocalcium phosphate, salt, vitamin-mineral premixture, L-lysine $\mathrm{HCl}$

Obtained results were processed statistically by variance analysis and differences between averages using t-test.

\section{Results and Discussion}

\section{a) Lactation period}

In the trial, the possibility for introduction of high protein plant feedEkofish meal as substitution of fish meal in nutrition of sows in lactation, suckling and weaned piglets was investigated.

Obtained results (table 4) have shown that sows of the first group control, fed diets with fish meal, lost during lactation period $16,82 \%$ of their own body mass. Group of sows fed diets containing investigated feed lost by $6,18 \%$ less of their own body mass compared to animals in control group. After weaning, it took in average 9,0 days for sows in control group to recover before next insemination, whereas in trial group average service period was only 7,4 days, which is shorter by average 1,6 feeding days (table 4).

In regard to feed consumption during lactation (table 4), nutrition of sows with control mixture resulted in average daily consumption of feed of $3,84 \mathrm{~kg}$. Introduction of plant high protein feed into mixture during lactation caused significant $(\mathrm{P}<0,05)$ decrease of consumption, in average by $0,18 \mathrm{~kg}$ or $4,69 \%$ compared to control group.

No significant difference in number of live born and still born piglets was established. Control group of piglets fed diets containing fish meal realized by 0,7 more weaned piglets per litter compared to trial group of pigs. No significant difference in rate of growth of piglets during suckling period . 
was established regardless of the composition of investigated mixtures. Use of investigated feed in mixture for piglets during lactation induced increased consumption of pre-starter by $1,1 \mathrm{~kg}$ or $12,66 \%$ per litter in relation to control group of piglets (table 4).

Table. 4. Performance of the sows and suckling piglets in the experiment

\begin{tabular}{|c|c|c|}
\hline Group & $\begin{array}{c}1 \\
\text { control }\end{array}$ & $\begin{array}{c}2 \\
\text { experimental }\end{array}$ \\
\hline \multicolumn{3}{|c|}{ Lactating sows } \\
\hline Fish meal in the diet & + & - \\
\hline Plant highprotein feedstuff in the diet & - & + \\
\hline Body mass of sows before farrowing, $\mathrm{kg}$ & 234,2 & 228,8 \\
\hline Body mass of sows at the end of lactation, $\mathrm{kg}$ & 194,8 & 192,7 \\
\hline \multicolumn{3}{|l|}{ The losses of body mass of sows, $\%$} \\
\hline *before farrowing/ at weaning & 16,82 & 15,78 \\
\hline Compared to the control group, $\%$ & - & $+6,18$ \\
\hline Average daily feed consumption, $\mathrm{kg}$ & $3,84^{\mathrm{a} * *}$ & $3,66^{\mathrm{a}}$ \\
\hline Service period, days & 9,0 & 7,4 \\
\hline \multicolumn{3}{|c|}{ Suckling piglets - creep feeding } \\
\hline Duration of the lactation period, days & 28,1 & 28,4 \\
\hline Number of liveborn piglets/litter & 11,70 & 10,44 \\
\hline Number of egalized liveborn piglets/litter*** & 11,10 & 11,55 \\
\hline Number of stillborn piglets/litter & $\mathbf{0 , 5 0}$ & $\mathbf{0 , 3 0}$ \\
\hline Number of weaned piglets/litter & 9,70 & 9,00 \\
\hline Average body mass of piglets at farrowing, $\mathrm{kg}$ & 1,417 & 1,473 \\
\hline Average body mass of piglets at weaning, $\mathrm{kg}$ & 7,29 & 7,27 \\
\hline Average daily gain of piglets, $g$ & 210 & 208 \\
\hline Compared to the control group, $\%$ & - & $-0,95$ \\
\hline Consumption of prestarter/litter, $\mathrm{kg}$ & 8,53 & 9,61 \\
\hline Compared to the control group, $\%$ & - & $+12,66$ \\
\hline
\end{tabular}

*) $1^{\text {st }}$ control group weighed 9.9 days, and $2^{\text {nd }}$ experimental group on 10.3 days before farrowing,

**)The same letters in the row over the average values mark statistical difference on the level $P<0.05$.

***) After the colostrum consumed, the number of suckling piglets was unified.

b) Weaning period

In the weaning period, during 51 feeding days, piglets of control group 
fed diets with fish meal, realized average daily gain of $309 \mathrm{~g}$ (table 5). Introduction of investigated Ekofish into isoprotein mixtures had no significant effect on growth piglets. No significant difference in consumption and conversion of feed between investigated groups was established.

In table 6 are given indicators of economical justification for introduction of Ekofish meal into mixtures for piglets in weaning. Its use in mixtures reduces the cost of feed by $4,46 \%$ so for the same feed conversion cost of gain of piglets fed diets containing Ekofish is more favourable by $4,73 \%$ compared to control group of animals, which confirms the justification for use of this feed from the nutritive and economical standpoint of view in nutrition of this pig category.

Table 5. Performance of weaned piglets in the experiment

\begin{tabular}{|c|c|c|}
\hline Group & $\begin{array}{c}1 \\
\text { control }\end{array}$ & $\begin{array}{c}2 \\
\text { experimental }\end{array}$ \\
\hline \multicolumn{3}{|l|}{ Weaned piglets } \\
\hline Fish meal in the diet & + & - \\
\hline Plant highprotein feedstuff in the diet & - & + \\
\hline Body mass of piglets at the beginning of experiment, $\mathrm{kg}$ & 8,21 & 8,21 \\
\hline Body mass of piglets at the end of experiment, $\mathrm{kg}$ & 23,99 & 23,90 \\
\hline Duration of experiment, days & 51 & 51 \\
\hline Average daily gain of piglets, $g$ & 309 & 307 \\
\hline Compared to the control group, $\%$ & - & $-0,65$ \\
\hline Average daily feed consumption, $\mathrm{kg}$ & 0,682 & 0,674 \\
\hline Compared to the control group, $\%$ & - & $-1,17$ \\
\hline Feed conversion ratio, $\mathrm{kg}$ & 2,20 & 2,19 \\
\hline Compared to the control group, $\%$ & - & $+0,45$ \\
\hline
\end{tabular}

Table 6. Economic analysis of the use of plant highprotein feedstuff in the nutrition of weaned piglets in the experiment

\begin{tabular}{|l|c|c|}
\hline \multicolumn{1}{|c|}{ Group } & $\begin{array}{c}1 \\
\text { control }\end{array}$ & $\begin{array}{c}2 \\
\text { experimental }\end{array}$ \\
\hline \multicolumn{2}{|c|}{ Weaned piglets } \\
\hline Fish meal in the diet & + & - \\
\hline Plant highprotein feedstuff in the diet & - & + \\
\hline The price of the diets, \% & $\mathbf{1 0 0 , 0 0}$ & $\mathbf{9 5 , 5 4}$ \\
\hline Feed conversion ratio, \% & $\mathbf{1 0 0 , 0 0}$ & $\mathbf{9 9 , 5 4}$ \\
\hline The price of the weaned piglets, \% & $\mathbf{1 0 0 , 0 0}$ & $\mathbf{9 5 , 2 7}$ \\
\hline Compared to the control group, \% & - & $+\mathbf{4 , 7 3}$ \\
\hline
\end{tabular}


Main ingredients of the investigated high protein plant feed are soy bean protein isolates, soy bean protein concentrates, full fat soy bean and soy bean meal (Adamović et al., 2006).

In case of soy bean products, hydrolyzed soy bean protein is excellent source of nutritious substances for piglets (Ferrini et al., 2004). Piglets fed products containing soy bean protein can progress equally as piglets fed diets containing fish meal (Davis et al., 2000; Min et al., 2003; Sardi et al., 2005). Soy bean protein isolates can be good alternative (Ebert et al., 2004) and due to arginine even superior to whey protein (Ebert et al., 2005), although inferior to casein (Junghans et al., 2004), i.e. they can replace up to $50 \%$ of skimmed milk protein powder (Junqueira et al., 2004) in piglet nutrition. Piglets fed soy bean isolates in mixture have better utilization of feed and less incidence of diarrhea (Jones et al., 1990; Kiers et al., 2003) and by measuring of digestibility in ileum their superiority over diets based on concentrated soy bean protein was established (Barriero et al., 2006).

Compared to soy bean meal, isolates have demonstrated their superiority (Jones et al., 1990) due to better lysine digestibility (Sohn et al., 1994) and better development of intestinal villus and crypt in small intestine ( $L i$ et al., 1990; $L i$ et al., 1991) which in general influences better piglet production (Lenehan et al., 2003). In nutrition of weaned piglets, investigated Ekofish resulted in great stimulative effect and its use can be recommended (Kovčin et al., 2006).

It is certain that the effect of introduction of plant protein sources depend on percentage of their inclusion into mixtures, processing method and age of pigs. Improved efficiency of use of plant proteins can be attributed to the adaptability of the digestive system in pigs (Kidder and Manners, 1980).

\section{Conclusion}

The effects of the investigated plant protein feed Ekofish meal are investigated as substitute for fish meal in nutrition of sows, suckling and weaned piglets. Obtained results demonstrated that introduction of investigated feed in diets did have following effects:

- Lower losses of body mass of sows in lactation by $6,2 \%$ and shorter service period by 1,6 days compared to nutrition based on fish meal,

- Fewer weaned piglets by 0,7 piglets/litter compared to treatment with fish meal in diet,

- Almost identical gain in suckling and weaned piglets, 
- Increased consumption of mixture used for additional feeding of suckling piglets by $1,1 \mathrm{~kg} /$ litter compared to indicator realized in group fed diets with fish meal,

- There was no difference in production of weaned piglets regardless of the use of fish meal or Ekofish meal in diets,

- Analysis of the cost of gain of weaned piglets showed that use of Ekofish meal reduces the cost of gain by $4,73 \%$ compared to the group fed diet with fish meal.

In general, obtained results have shown that the use of Ekofish meal can be recommended in nutrition of sows, suckling and weaned piglets.

\title{
EFEKTI ZAMENE RIBLJEG BRAŠNA BILJNIM VISOKOPROTEINSKIM HRANIVOM U ISHRANI KRMAČA I PRASADI
}

\author{
B. Živković, W. Migdal, V. Veselinović, Č. Radović, O. Kosovac, \\ M. Fabjan
}

\section{Rezime}

Ispitivani su efekti korišćenja visokoproteinskog hraniva biljnog porekla - Ekofish meal u ishrani krmača u laktaciji, prasadi na sisi i u odgoju.

Imajući u vidu naša ranija pozitivna iskustva o korišćenju sličnog hraniva u ishrani odbijene prasadi i svinja u tovu, cilj ovoga rada je bio da se ocene efekti korišćenja visokoproteinskog hraniva zasnovanog na biljnim izvorima proteina u obrocima krmača u laktaciji, prasadi na sisi, i u odgoju.

Ispitivano hranivo je proizvedeno po određenoj tehnologiji u pogonima kompanije Bankom u Srbiji.

Istraživanja su izvedena na eksperimentalnoj farmi svinja Instituta za stočarstvo, Beograd-Zemun u Srbiji.

Dobijeni rezultati su pokazali da je u izonitrogenim smešama uvođenje ispitivanog hraniva umesto ribljeg brašna imalo pozitivne efekte izražene za $6,18 \%$ manjim gubicima telesne mase krmača tokom laktacije, za 1,6 dana kraćim servis periodom, skoro istim prirastom (razlika 2 grama) kod prasadi na sisi, povećanom potrošnjom predstartera za $1,1 \mathrm{~kg} / \mathrm{leglo}$ kod prasadi 
tokom prihranjivanja, sličnim ali za 4,73\% jeftinijim prirastom uz sličnu konverziju hrane kod prasadi u odgoju.

U celini dobijeni rezultati su pokazali da se preporučuje korišćenje biljnog visokoproteinskog hraniva $u$ ishrani krmača, prasadi na sisi $\mathrm{i} u$ odgoju.

\section{Zahvalnost}

Koristimo priliku da se zahvalimo kompaniji Bankom, Novi Beograd za obezbeđenje Ekofish meala za izvođenje ogleda.

\section{References}

ADAMOVIĆ M., VESELINOVIĆ V., TOMOVIĆ R., VRANJEŠ B. (2006): Efikasnost korišćanja zamene za riblje brašno - Ekofish meal u ishrani prasadi po odbijanju. XVII Inovacije u stočarstvu, Biotehnologija u stočarstvu, Vol. 22, 669-677.

BARRIERO A. A., MARIA SOUZA T. C. R., LANDIN G. M., SOSA A. G. B., BARREYRO A. A. (2006): Digestibility of nutrients in piglets fed diets with isolated or concentrate soy protein. Téc. Pecu Méx., 44 (3), 301-311.

DAVIS M. E., BROWN D. C., MAXWELL C. V., JOHNSON Z. B., WALKER W. R., HAQUE A. K. M. H. (2000): Potential for an extruded multiple protein complex (Profound ${ }^{\mathrm{TM}}$ ) as a replacement for fish meal in early weaned pig diets. Journal of Animal Science, Vol. 78, Suppl. 1, 180.

EBERT A., BERMAN A.S., HARREL R.H., CORNELIUS S.G., ODLE J. (2004): M97 Liquid diets containing vegetable proteins accelerate piglet growth above milk-protein-based diets. Journal of Animal Science, Vol. 82, Suppl. 1, 24.

EBERT A., BERMAN A., HARREL B., CORNELIUS C., ODLE J. (2005): Vegetable Protein Sources for diets of Suckling Piglets. North Carolina State University, Animal Science Department Report.

FERRINI G., BORDA E., MARTINEZ PUIG D., GARCIA MANZANILLA E., MARTIN -ORUE S., PEREZ J. (2004): Influence of a soy protein hydrolizate on the productive performance of early weaned pigs under a enterotoxigenic E. Coli (ETEC) collibacilosis or under an healthy status. Journal of Animal Science, Vol. 82, Supplement1, 24.

HOORICK VAN H. (2003): Solutions for more strict feeding-regulations: Vitaprotein 50 - the vegetable replacer for fishmeal; aromabiotic - the natural replacer for the growth promoters. Biotechnology in Animal 
Husbadry, 19 (5-6), 367-373.

JONES D. B., HANDCOCK J. D., REDDY P. G., KLEMM R. D., BLECHA F. (1990): Effect of replacing dried skim milk with specially processed soy products on digestibility of nutrients and growth performance of nursery pigs. Swine day, Kansas State University, 37-40.

JONES D. B., HANDCOCK J. D., REDDY P. G., KLEMM R. D., BLECHA F. (1990): Effect of replacing dried skim milk with soy products on function and morphology of the small intestine in nursery pigs. Swine day, Kansas State University, 41-44.

JUNGHANS P., DERNO M., JENTSCH W., KUHLA S., BEYER M. (2004): Effect of a soy protein diet on protein and energy metabolism and organ development in protein-restricted growing pigs. Arhiv of Animal Nutrition, 58 (6), 453-461.

JUNQUEIRA O. M., SILZ Z. T. LILIAM ARAUJO L. F., LOPEZ E. L., DUARTE F. KARINA (2004): Substitution levels of dry skim milk for isolated soybean protein in diets for weaned pigs. Rev. Bras. Zootec., Vol. $33, \mathrm{~N}^{\mathrm{o}} 6$.

KIDDER D. E., MANNERS M. J. (1980): The level of distribution of carbohydrases in small intestine mucosa of pigs from 3 weeks of age to maturity. British Journal of Nutrition, 43: 141-153.

KIERS J. L., MEIJER J. C., NOUT M. J., ROMBOUTS M. J., NABUURS M. J., VAN DER MEULEN J. (2003): Effect of fermented soya beans on diarrhoea and feed efficiency in weaned piglets. Journal Applied Microbiology, 95 (3), 545-552.

KOVČIN S., LANIŠTANIN D., MAĆOŠ M. (2006): Ekolak i Ekofish u ishrani odlučene prasadi. Savremeni Farmer, God. VII, Br. 28, 32-33.

LENEHAN N. A., GOODBRAND R. D., TOKACH M. D., DRITZ S. S., EISSEN J. L., BARKER M. R., FRANTZ N. Z., GROESBECK C. N., IWASAWA T., KEEGAN T. P., LAWRENCE K. R. (2003): Evaluation of different soya protein concentrate source on growth performance of weanling pigs. Kansas State University, Swine Days, 1-4.

LI D. F., NELSSEN J. L., REDDY P. G., BLECHA F., KLEMM R. D., GOODBAND R. D. (1990): Interrelationship between hipersensitivity to soybean proteins and growth performance in early-weaned pigs. Swine day, Kansas State University, 45-51.

LI D. F., NELSSEN J. L., REDDY P. G., BLECHA F., KLEMM R. D., GIESTING D. W., HANCOCK J. D., ALLEE G. L., GOODBAND R. D. (1991): Measuring suitability of soybean products for early-weaned pigs with imunological criteria. Journal of Animal Science, Vol. 69, $\mathrm{N}^{\mathrm{o}}$ 8, 3299- 
3307.

MIN B. J., KIM I. H., HONG J. W., KWON O. S., LEE W. B., SON K. S., KIM J. H., SHO W. C. (2003): Effect of feeding processed soy protein on the growth performance in weanling pigs. Journal of Animal Science, Vol. 81, Suppl. 1, 206.

SARDI L., PAGANELL R., PARISINI P., SIMIOLI M., MARTELLI G. (2005): The replacement of fishmeal by plant proteins in piglet production. Italian Journal of Animal Science, Vol. 4, Supplement 2, 449-451.

SOHN K. S., MAXWELL C. V., SOUTHERN L. L., BUCHANAN D. S. (1994): Improved soybean protein sources for early-weaned pigs: II. Effects on ileal amino acid digestibility. Journal of Animal Science, vol. 72, Issue 3, 631-637.

ŽIVKOVIĆ B., PETROVIĆ M., KOSOVAC O., RADOVIĆ Č., FABJAN M. (2006): Effect of use of Vitaprotein 50 as fish meal substitute in nutrition of growing-fattening pigs. The $35^{\text {th }}$ International Session of Scientific Communications, The Scientific Papers of the Faculty of Animal Science, Bucharest, 171-175.

ŽIVKOVIĆ B., MIGDAL W., KOVČIN S., RADOVIĆ Č ., BURMAZOVIĆ S., FABJAN M., KOSOVAC O. (2007): Effect of use of Vitaprotein 50 as fish meal substitute in nutrition of weaned piglets. Annals of Animal Science, Kraków (u štampi).

ŽIVKOVIĆ B., VESELINOVIĆ V., MIGDAL W., RADOVIĆ Č., FABJAN M., KOSOVAC O., MARINKOV G., PEJČIĆ S. (2007): Nutritivna vrijednost visokoproteinskog krmiva biljnog porekla u hranidbi svinja. 14. Međunarodno savjetovanje “Krmiva 2007”, Opatija, 11.-14.06.2007. godine, 30-31.

ŽIVKOVIĆ B., MIGDAL W., PETROVIĆ M., RADOVIĆ Č., FABJAN M. (2007): The effects of replacement of fish meal by plant protein feedstuff on the slaughter results of the fattening pigs. International Conference "Quality and safety in meat for consumers: from stable to table", Kaunas, Lithuania, 06.06.2007 - 07.06.2007. Animal Science, Volume 1, 156 -157. 